\title{
SEMANTIC FEATURES OF ENGLISH PHRASEOLOGICAL UNITS RELATED TO SPORT VOCABULARY
}

\author{
Mokhigul Khudoyberganova
}

Second Year Master's Student, Foreign Languages Department, Fergana State University, Uzbekistan

ABSTRACT

This article describes the semantic features, stylistic means of English phraseological units related to sports. It has also been pointed out that the study of the interrelationship of terminology and phraseology is one of the new and at the same time topical issues of modern linguistics. In linguistics, there are such stable, stable phrases that create the sensitivity and imagery of speech, the emergence of which is strongly associated with people's views and attitudes towards things and events in objective existence. Members of society use linguistic means based on various comparisons in order to express their views and attitudes towards things in an exciting, figurative and influential way. In this sense, the person, thing, event, and scene depicted is often interpreted through images or analogies that are familiar to the listener. As a result, the effect and image of speech become stronger and larger. We know that phraseological units and stylistic devices are among such tools that increase the effectiveness of speech.

KEYWORDS: - Stylistic means, phraseological unit, stylistic device, literary text, connotative, discourse, extralinguistic.

\section{INTRODUCTION}

Just as the study of phraseological and stylistic problems plays an important role in the translation of linguistic and literary texts, today the study of specific aspects of linguistics, in particular, in terms of terminological systems, is also relevant. "The study of the relationship between terminology and phraseology is one of the new, as well as topical issues of modern linguistics" [1].

Since there is an integral connection between the terminology of physical education and sports in English and the general literary language, universal lexical-semantic processes are observed in the terminological system. While most of the terms that have passed from sports terminology to general use continue to be expressed in their original form without changing their form, it is also observed that some terms are used in new meanings. Terminological units with such a stylistic color, of course, create some difficulties in the translation of field terms, in their interpretation. In general, phraseological and stylistic units in linguistics are semantically and structurally expressive-emotional, functional-stylistic, connotative, so translating in accordance with the norms of this or that language is a very complex and responsible task. This does not bypass the terminological system either. Such phraseological and stylistic units are reflected in communication as portable and descriptive means of speech, which is explained by their complexity in lexical-semantic, pragmatic and structural aspects. Another important aspect of phraseology in sports is that 
CURRENT RESEARCH JOURNAL OF PHILOLOGICAL SCIENCES 2(11):

124-127, November 2021

DOI: https://doi.org/10.37547/philological-crjps-02-11-27

ISSN 2767-3758

(C)2021 Master Journals

Crossref do

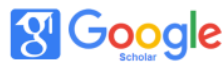

Accepted $25^{\text {th }}$ November, 2021 \& Published $30^{\text {th }}$ November, 2021

they are not literally translated from one language to another. The meaning of phraseologies does not depend on the primary meaning of the words involved as structural units [2].

\section{Methodology AND Materials}

In the course of the research, we collected phrases related to sports from the literature, newspapers and magazines in this field, English-language television broadcasts of foreign countries organized in English [3,5,7,8,10,11]. In addition, "Explanatory dictionary of Russian-Uzbek terms of physical culture and sports" (1961), published by R.Ismailov and M.Norkin, N.Tursunov's "Anglo-Russian dictionary of sports terms" (2005), Y.Khamroeva's "Dictionary of Uzbek language Explanatory dictionary of self-explanatory words "(2007)," Uzbek-Russian-English dictionary of sports terms "and" English-Uzbek-Russian dictionary of sports terms "(2015) published by H.Rafiev, Sh.Butaev were involved in the research analysis. It should be noted that we have identified and analyzed more than 150 phrases related to sports from the book "Anglo-Russian Phraseological Dictionary" (1984) by AV Kunin alone. Although these phraseological expressions are not quantitative, they have made it possible to identify and reveal the lexical-semantic, structural-functional features of English sports phrases.

\section{RESULTS}

In fact, in the connotative semantics of phraseological units related to sports, there are features and professional prototypes related to human activity and character. To be more precise, such professional prototypes are an inspiring force that reveals the inner abilities of athletes, moves them to victory. In many sources, units of portable meaning are referred to as phraseological units.
Such prototypes, which are present in the internal lexical-semantic, cognitive properties of phraseological units, are the main source in the formation of connotation. According to VM Mokienko, who specifically studied the emotiveexpressive nature of phraseological units, "Like other languages, English and Russian have impressive, figurative phraseological units. In order to achieve adequacy in their translation, it is necessary to correctly understand whether the phraseology in each language is used in a figurative or fixed sense. Otherwise, the meaning of phraseological units may change completely or be misinterpreted. To do this, it is first necessary to determine the original content of FBs in the context or to use special phraseological dictionaries. Because they have portable, connotative meanings, their interpretation and content cannot be found in ordinary dictionaries "[4].

It is known that in linguistic sources phraseological units are divided into three types: a) phraseological integrity; b) phraseological compounds; c) phraseological confusions (idioms). Phrases in which one word is lexically and semantically correct and the other is used in a figurative sense are called phraseological compounds. For example: to relax (rest - in the literal sense, to take out - in the figurative sense) or to be exhausted (without - in the literal sense, to be exhausted - in the figurative sense). When the meanings and grammatical aspects of the words in a sentence are combined, phrases that give a common portable meaning are called phraseological units. For example: to pull the heart behind (fear), to lift to the sky (praise). Phraseologisms that do not have any lexical connection between the meanings of the words in them and the meanings of the expressions are called phraseological confusions. For example: if it falls into the mill, the whole exit, pressing the iron in the heat, taking the mouse's nest for a thousand coins, and so on. 
CURRENT RESEARCH JOURNAL OF PHILOLOGICAL SCIENCES 2(11):

124-127, November 2021

DOI: https://doi.org/10.37547/philological-crjps-02-11-27

ISSN 2767-3758

(C)2021 Master Journals

Crossref doi

\section{Discussion}

Phraseologisms are usually formed on the basis of free word combinations in a language. However, they acquire a portable meaning and are absorbed into the language as a result of their components being combined and applied as a whole. Some types of phraseology also reflect national traditions. When translating them from one language to another, it is advisable to use their alternatives without literally translating the components of the phrase [5].

The use of sports-related phraseological units in oral and written communication is widespread in the United Kingdom, the United States, Australia, and other English-speaking countries. One of the main reasons for this is the popularity of sports competitions among the peoples of the world, and the other is explained by the socio-political influence of Britain on the colonial states under its control. Today, the United Kingdom and the United States continue to lead in all areas, especially in sports. In this sense, we see that the origin of some sports (football, cricket, rugby, basketball, baseball, hockey, golf, boxing, American football) is associated with these countries.

In the course of the research, we made sure that phraseological units related to the abovementioned sports in modern English can be classified into several types.

1. Phraseological units related to sports, which directly express the etymology of the origin of the sport. For example: Shoot the ball into one's own goal (in football); get to first base - to achieve initial success, to take the first step (in baseball); hit below the belt - a forbidden blow to the lower part of the waist (in boxing); unjust, cruel action; carry the ball - to take responsibility [6];

2. Phraseological units related to sports, which indirectly express the etymology of the origin of the sport. For example: Also ran - unlucky (tolei low), unlucky participant in sports competitions, unsuccessful athlete. Example: I'm afraid he'll always be one of life's also rans: Unfortunately, he never succeeds.

English: Wilkie and Hencken are nearly 3 sec faster than the "also rans", a huge margin in swimming ]. It is also possible to include the following sportsrelated phraseological units in this group. Be out for the count - to lose, to be knocked out, to be unable to stand up for 10 seconds (in boxing); double cross - deception, deception, extortion, use of prohibited methods in sports games: 1) $\mathrm{He}$ always remembered that double cross - He was always thinking about how he was deceived; 2) I remarked that this looked like the biggest double cross in history - I apparently felt that this was the biggest extortion in human history; 3 ) Tom is mad at Jane because she double crossed him on the sale of his car.

3. To this group we can include FBs related to semisports. Phraseological units of this type do not give a person any idea about the origin and etymology of sports. Most of them are not only phrases related to sports, but also compound lexemes related to social, military, navy and other fields. For example: To catch the card - 1) fishing; 2) sinking into a deep place; head to head - the governor and the senator went head to head in a spontaneous debate: the governor and the senator struggled with courage in an unplanned debate); hands down - easy to reach (Example: The other team are two men short, in theory, at least, we ought to win hands down):

Conclusion: The use of phraseological units in the field of sports in oral and written discourse is formed on the basis of certain extralinguistic factors, ie the interaction with certain sports, sports competitions and events, which reflect specific situations, realities. There are also expressions in the field of physical education and sports in English that can be said to have been formed as a result of the combination of other words into a particular word. We can also observe that some of them have 
CURRENT RESEARCH JOURNAL OF PHILOLOGICAL SCIENCES 2(11):

124-127, November 2021

DOI: https://doi.org/10.37547/philological-crjps-02-11-27

ISSN 2767-3758

(C)2021 Master Journals

crossref do) 8: Google

Accepted25 $5^{\text {th }}$ November, 2021 \& Published 30th November, 2021

a polysemantic property.

For example: sonsolation race -

1) horse racing;

2) the participant who has lost (lost) in the previous competition;

3) to have fun (on horseback), to jump without obstacles; consolation prize - a consolation prize (two hundred runners-up will get a consolation prize [7] - a prize will also be awarded to two hundred runners-up); consolation heat - running, running a certain distance as a test; consolation goal - an impressive goal, a consolation goal.

\section{REFERENCES}

1. Usmonov S. Some issues of uzbek terminology - Toshkent, 1968 .-- 148 p.

2. Akobirov F. Lexicographic development of terminology in bilingual dictionaries. Abstract of the thesis. diss. ... Cand. philol. Sciences. Tashkent, Author. diss. ... Cand. philol. sciences.

- Tashkent, - 1969 .-- $25 \mathrm{~s}$

3. Mirzoev Z. Sports terms in Tajik and English: Dis. ... Cand. philol. sciences. - Dushanbe, 2005 -- $210 \mathrm{p}$.

4. Mokienko VM Riddles of Russian phraseology. - St. Petersburg: Avalon, 2005 --- 19 p.

5. Marchand $H$. The Categories and Types of Present-Day English Word-formation. München: C.H. Beck'sche Verlagsbuchhandlung, 1969. - P. 26-218.

6. Tim T. Sports, history and culture. Sport and politics: From Thatcher to Cameron - Who will be next? - 2015 -- P. 4-5.

7. Active study of English. - Moscow, 1988. -P. 710

8. Hornby A. S. The Advanced Learner's Dictionary of Current English. - London, 1974 -- P. 750.

9. Shagalova E.N. Dictionary of the latest foreign words. - M., 2017 .-- 895 s
10. http: //www.etymonline.com/index

11. www.collinsdictionary.com 